\title{
化膿性春椎炎の診断および治療方針の検討
}

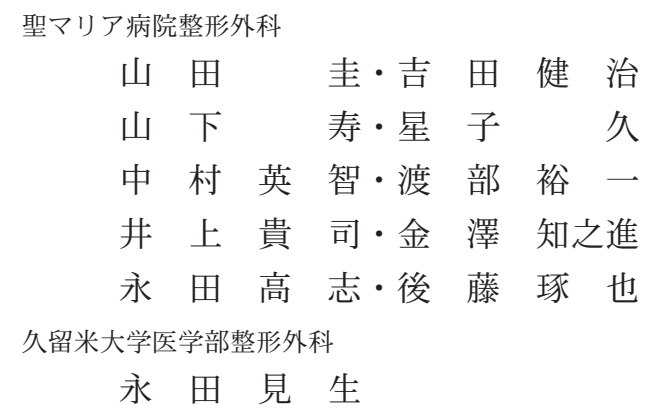

\section{Diagnosis and Treatment of Pyogenic Spondylitis}

\author{
Kei Yamada, Kenji Yoshida, Hisashi Yamashita, \\ Hisashi Hoshiko, Hidetomo Nakamura, Yuichi Watanabe, \\ Takashi Inoue, Tomonoshinn Kanazawa, Takashi Nagata, \\ and Takuya Goto \\ Department of Orthopaedic Surgery, \\ Saint Mary's Hospital, Fukuoka, Japan \\ Kensei Nagata \\ Department of Orthopaedic Surgery, \\ Kurume University, School of Medicine, Fukuoka, Japan
}

We report 39 patients with pyogenic spondylitis who were treated from 1987 to 2001. Their age ranged from 18 to 84 years (mean : 60.3 years). The follow-up period ranged from one month to 35 months (mean : 9.5 months). Seventeen patients suffered from complications, of whom 6 had diabetes mellitus, 3 had liver cirrhosis and 3 had rheumatoid arthritis. The most common pathogen was methicillin-sensitive Staphylococus aureus (MSSA, 6 cases) and methicillin-resistant Staphylococcus (MRSA, 3 cases). Ten cases had complications of the spinal epidural abscess. Thirty-eight cases were diagnosed MRI and scintigraphy. One case could not be diagnosed either by MRI or by scintigraphy at an early stage. Fifteen of these cases were treated conservatively and 24 were treated surgically, because of abscess with meningitis, neurological deficit and resistance to conservative treatment. Two out of the 10 cases of spinal epidural abscess sustained residual pain, and one showed residual neurological deficit. Fales-negative MRI results in diagnosis at early stages of pyogenic spondylitis should be noticed. Surgical treatment at an early stage is recommended for cases with these complications and/or spinal epidural abscess.

Key words : pyogenic spondylitis (化膿性脊椎炎), epidural abscess (硬膜外膿瘍), surgical treatment (手術治療) 


\section{はじめに}

化膿性春椎炎は近年 MRI の出現により診断は容易 となった．また化膿性脊椎炎の治療は抗生剂による保 存的治療が原則で一般に予後良好である。しかしわれ われはMRIを使用したが診断に難渋したり，保存的 治療中に䯣膜炎を発生し重症化した例を経験した。 そ こで当科で経験した症例から診断および治療方針につ いて検討を加えたので報告する.

\section{対象と方法}

対象は平成 1 年から平成 14 年 7 月までに当科にお いて化膿性春椎炎と診断され入院加療を行った 39 例 （男性 25 例，女性 14 例）である. 平均年齢は 60.3 歳, 平均観察期間は 9.5 か月であった. これらの症例から 近年の罹患傾向, 臨床型, 感染高位, 合併症の有無, および起炎菌について調査を行った。 また治療方法お よび結果から治療に影響を与えたと思われた因子につ いて統計学的に検討を加えた.

\section{結果}

当科において加療した症例数の推移は平成 1 年 1 例, 平成 3 年 2 例, 平成 5 年, 平成 6 年, 平成 8 年, 平成 9 年は各 1 例, 平成 10 年 5 例, 平成 11 年 8 例, 平成 12 年 7 例, 平成 13 年 3 例, 平成 14 年 9 例であった. 平成 10 年より增加傾向が認められ，特に他科から紹 介された症例の増加が認められた.

国分の分類 ${ }^{2}$ に従いその発症状態から分類すると, 発熱激痛を伴う急性型が 31 例, 亜急性型が 5 例, 慢 性型が 3 例で急性型が最も多かった。感染高位は䅡椎 2 例, 胸椎 4 例, 胸腰椎移行部 2 例, 腰椎 31 例と腰 椎がもつとも多く, 3 例で複数椎間の罹患があった.

基礎疾患は糖尿病 6 例, 肝硬変 3 例, 関節リウマチ 3 例, 潰瘍性大腸炎, 食道癌, 心筋梗塞, 腎孟腎炎, アルコール性肝障害がそれぞれ 1 例認められた。起炎 菌は血液培養ないし摘出された椎間板の細菌培養で検 查された。 MSSA 6 例, MRSA 3 例, 嫌気性グラム 陽性球菌 2 例, E. coli, Group 6 Salmonella, K. pneumoniae, E. cloacae, S. capitis, S. epidermidis が各 1 例ずつ検出された。あとの 13 例では菌は同定 されず，検出率 $56.7 \%$ であった，治療は基本的に抗
生剂による保存的治療を行つたが, 保存的治療に抵抗 した 24 例には手術的治療を行った。病巣が比較的椎 間板腔に限局し硬膜外膿瘍を合併しなかった 15 例に は経皮的病巣掻爬ドレナージを行った. 脊椎術後感染 の 1 例と広範囲に硬膜外膿瘍形成した 1 例には椎弓切 除および持続洗浄を施行した，下肢の不全麻痺を合併 した 3 例と䯣膜炎および硬膜外膿瘍を併発した 1 例で は椎弓切除および病巣掻爬を行った。包丁による頝椎 外傷後に䯇液漏を発生した 1 例には椎弓形成・硬膜綘 合術を行った。後腹膜腔に膿瘍が拡大した 1 例には後 腹膜腔ドレナージを行った。経過観察中 35 例は疼痛, 炎症所見ともに改善した。糖尿病と慢性腎不全があり 硬膜外膿瘍を合併した 1 例と合併症はなかったが硬膜 外膿瘍を合併した 1 例で炎症所見は改善したが疼痛が 残存した。 また腰椎破裂骨折に対する後側方固定術後 にMRSA に感染した 1 例と保存的に抗生剂を投与し たが 1 か月で投与中止とした 1 例に再発を認めた. こ のことから合併症ないし硬膜外膿瘍の存在が治療結果 に影響を与える可能性が考えられた，そこで合併症の 有無と治療効果の関連, さらに硬膜外膿瘍の有無と治 療効果の関連を統計学的に検討した. 治療効果を示す ものとして抗生剂投与期間を指標とし, 抗生剂の投与 は CRP および血沈值が改善するまで行った. 統計学 的検定は Student の $\mathrm{t}$ 一検定を使用した．硬膜外膿瘍 は 10 例が合併していた．硬膜外膿瘍合併群 10 例と硬 膜外膿瘍非合併群 29 例で抗生剂の投与期間を比較し たが, 硬膜外膿瘍合併群で $4.7 \pm 2.2$ か月, 硬膜外膿 瘍非合併群で $4.9 \pm 6.7$ か月と統計学的には有意差を 認めなかった．合併症の有無で抗生剂投与期間を比較 すると合併症なし群（16 例）で $5.8 \pm 7.3$ か月, 合併 症あり群（23 例）で $3.6 \pm 2.6$ か月で, 合併症なし群 でより長期に投与されている傾向はあったが, 統計学 的に有意差は認めなかった。

\section{症例}

(症例 1)

30 歳男性, 急性型。白血球 $10560 / \mathrm{mm}^{3}$, $\mathrm{CRP} 12.7 \mathrm{mg} / \mathrm{dl}$ と著明な炎症所見を認めた。単純 $\mathrm{X}$ 線上は骨融解像を認めなかった（図 1)，MRI 上 T2 で L3/4 間に高信号域を認めたが, 明らかな造影効果 は認めなかった（図 2)。同時期の Ga シンチでも異 常な集積は認めず明らかな感染病巣は不明であった. 


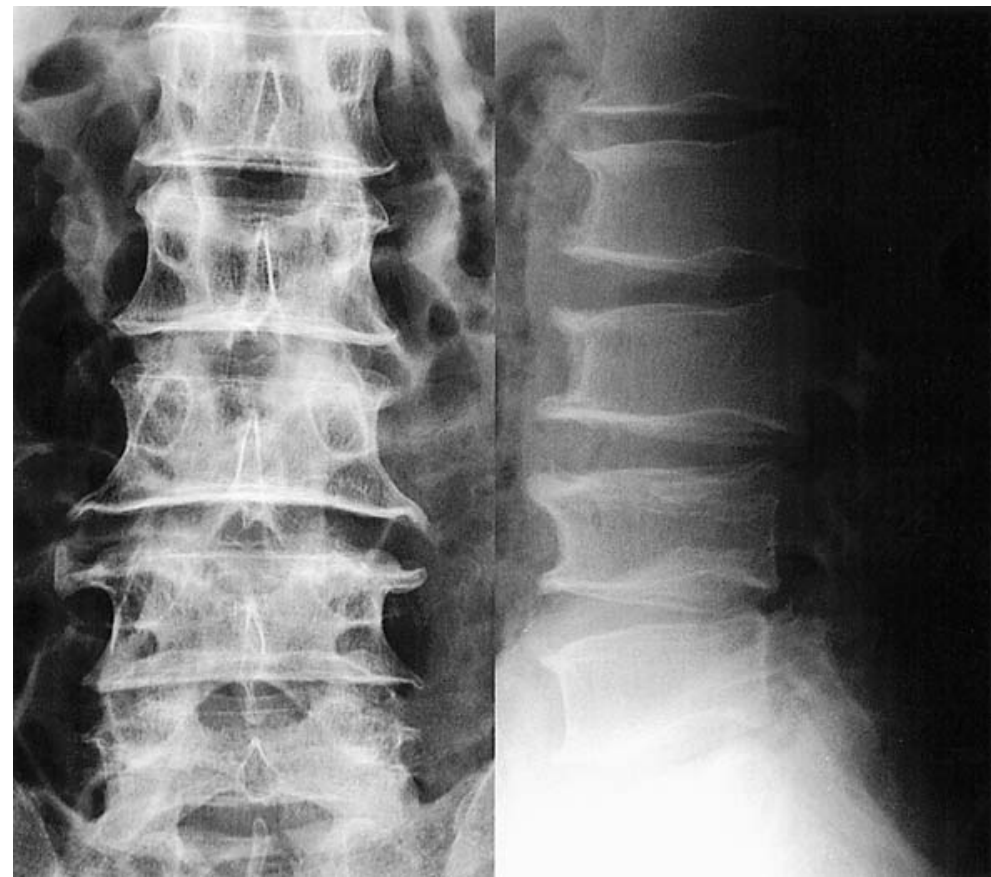

図 1 症例 $1 ; 30$ 歳男性，急性型。初診時単純 X 線. L3，4 に骨棘形成を認めた。終板 の破壊像は認めなかった。

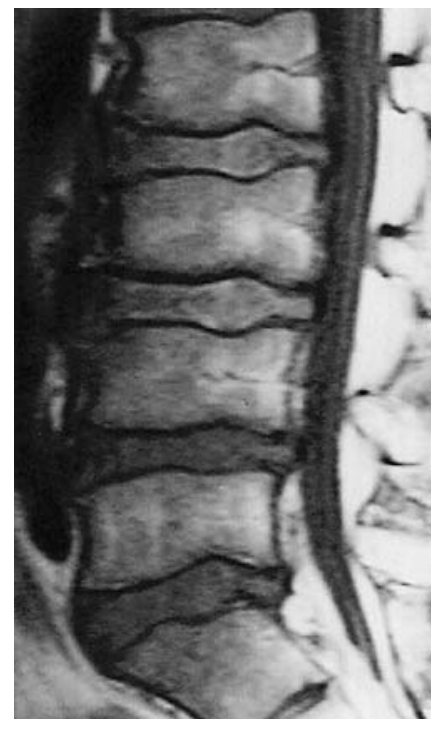

a

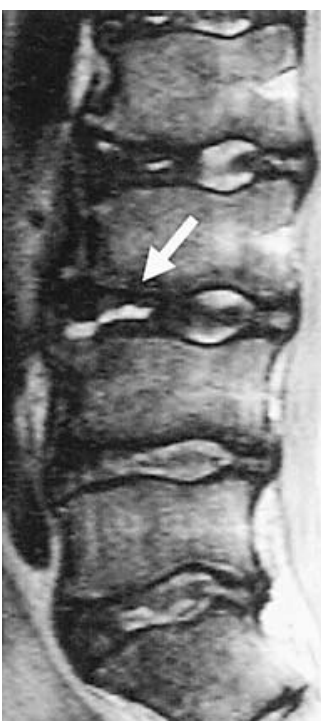

b
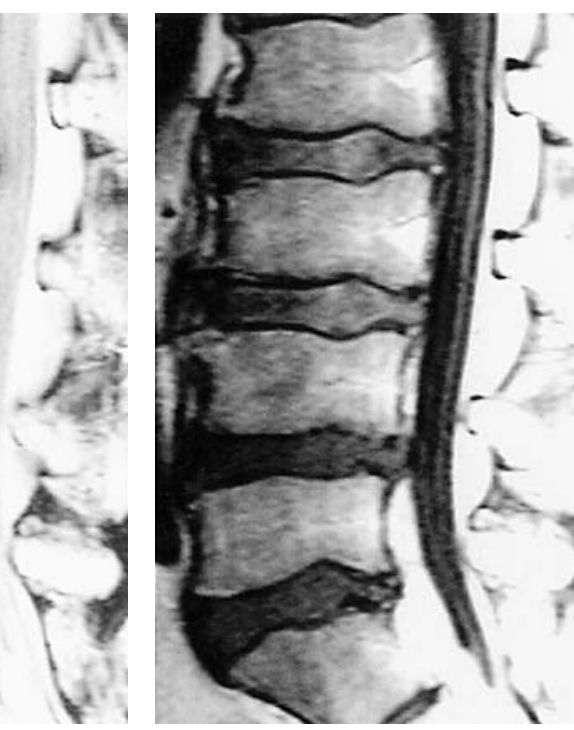

C

図 2 初診時 MRI

（a） T1 強調画像. 明らかな低信号域は認めなかった.

（b） T2 強調画像. L3/4 間椎間板前縁に軽度高信号域を認めたが（矢印），明らか な高信号域は見られなかった

(c) Gd 造影画像. 椎間板内に造影効果は認めなかった. 


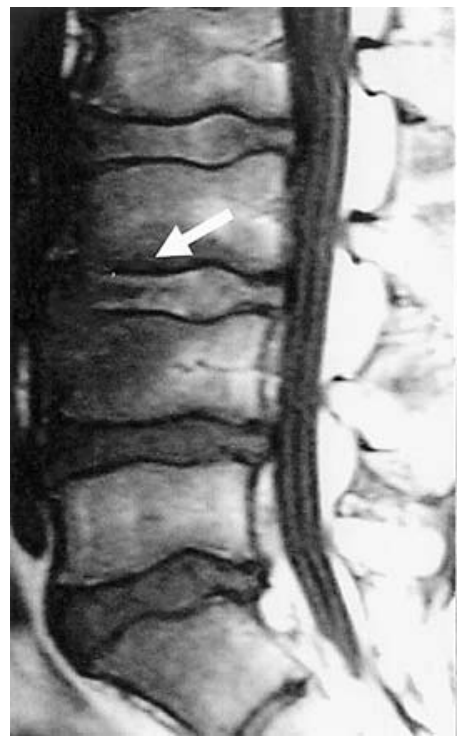

a

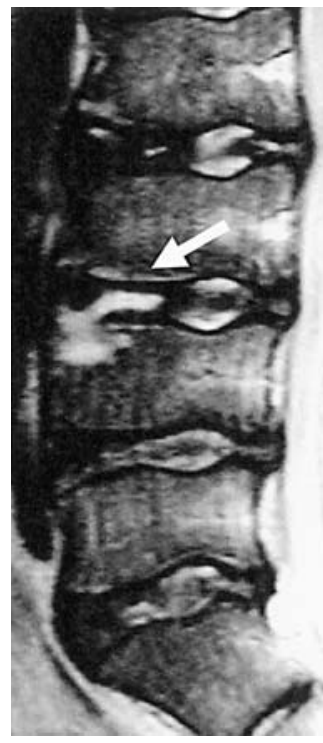

b

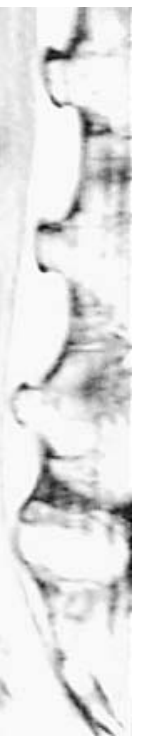

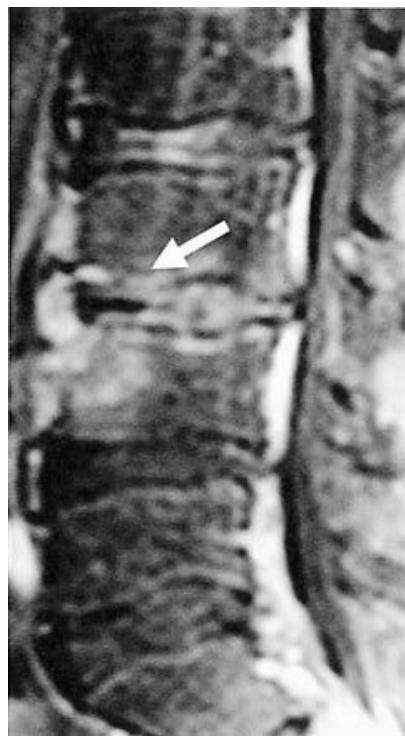

c

図 3 入院 3 週後 MRI

（a） T1 強調画像. L3/4 間椎間板前縁に低信号域を明瞭に認めた（矢印）.

(b) T2 強調画像. L3/4 間椎間板前縁に高信号域の拡大を認めた（矢印）.

（c） Gd 造影画像. L3/4 間椎間板内に造影効果を認めた。病巣は L4 椎体にまで波 及していた (矢印).

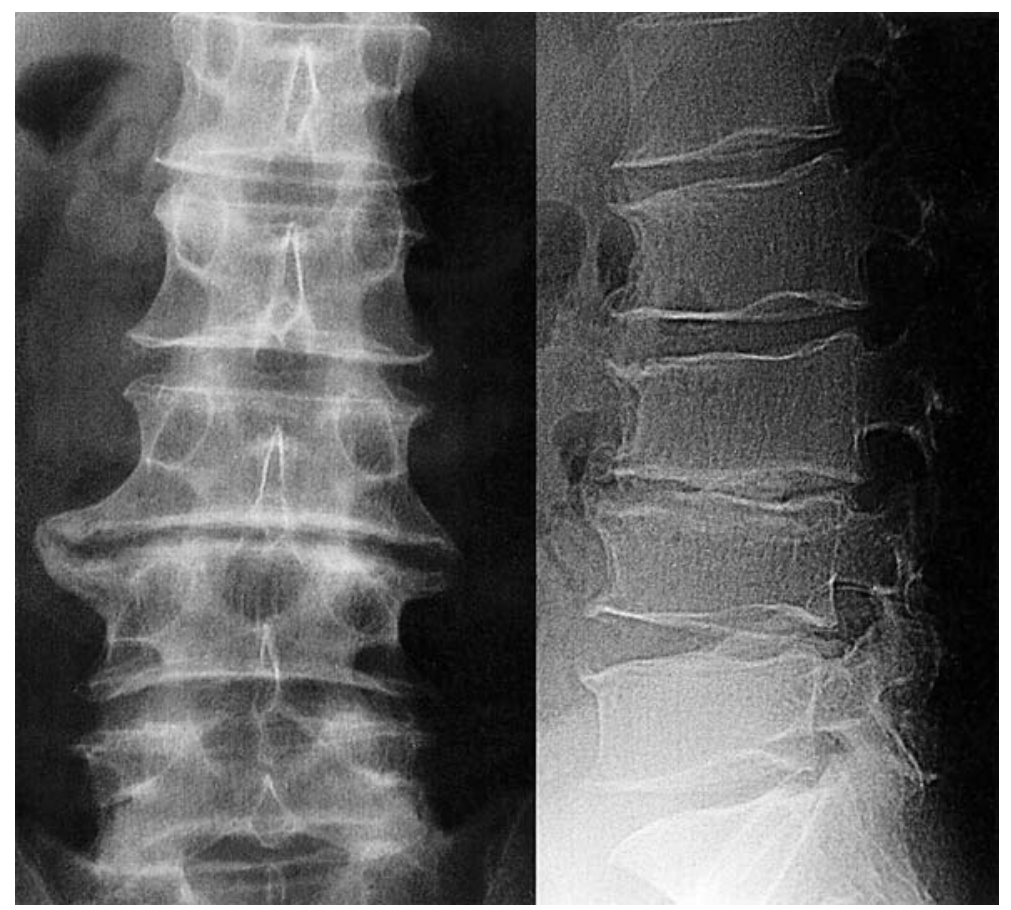

図 4 術後 1 年単純 X 線. L $3 / 4$ 椎間腔の狭小化を認めた.

$$
-214-
$$




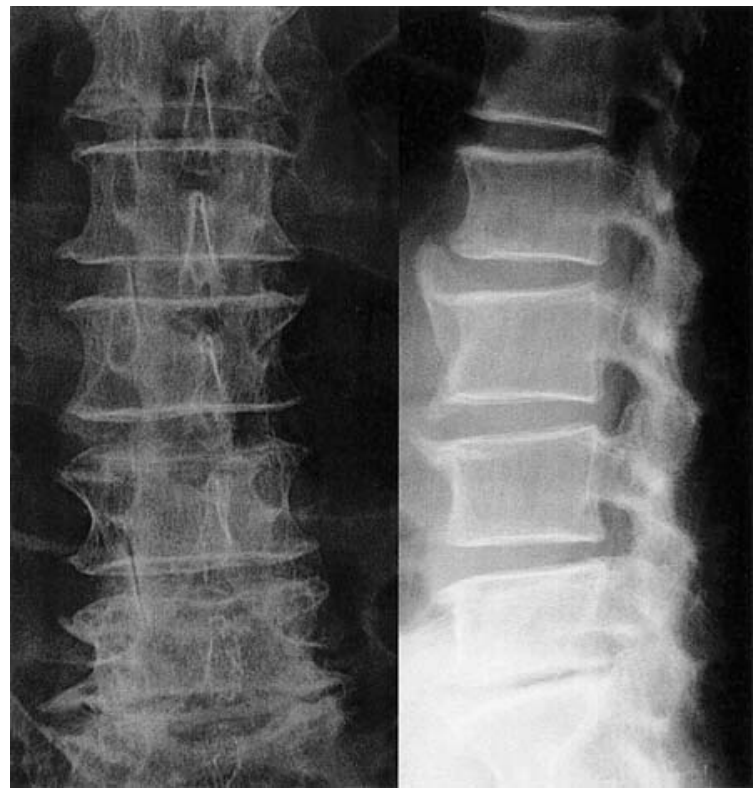

図 5 症例 $2 ; 73$ 歳女性，急性型。初診時単純 X 線。椎体の骨棘形成および L5/S1 椎間 腔の狭小化を認めた。明らかな骨溶解像は認めなかった。

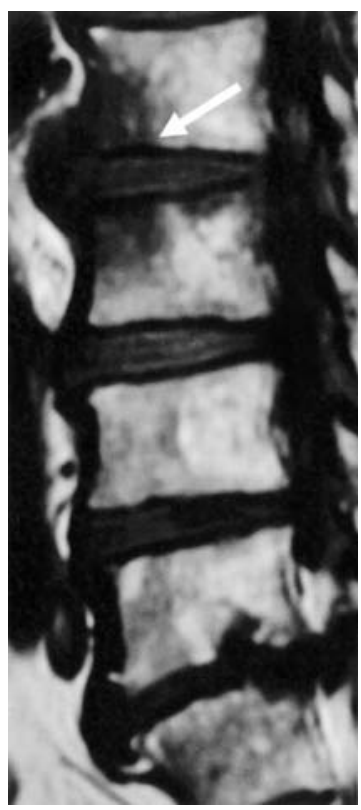

a

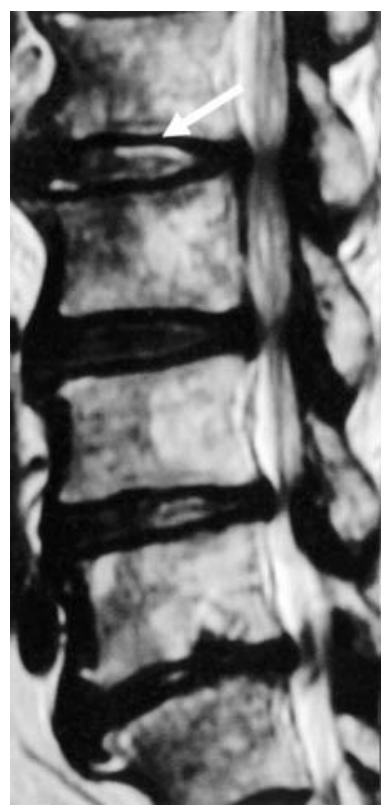

b

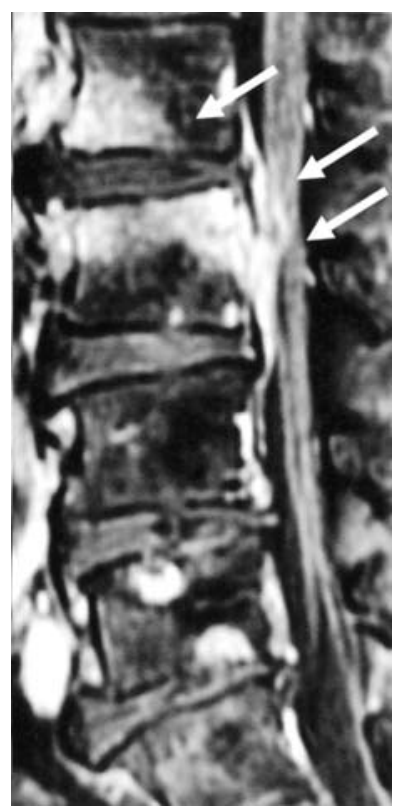

c

図 6 （a） T1 強調画像. L2 $/ 3$ 椎間板に低信号域を認めた（矢印）.

（b） T2 強調画像. L2/3 椎間板前縁に高信号域を認めた（矢印）。 L2/3 間， L3/4 間, L4/5 間, L5/S1 間で硬膜の圧迫像を認めた.

(c) Gd 造影画像. L2，3 椎体後縁に造影される mass および椎体内の造影効果を 認めた（矢印). 


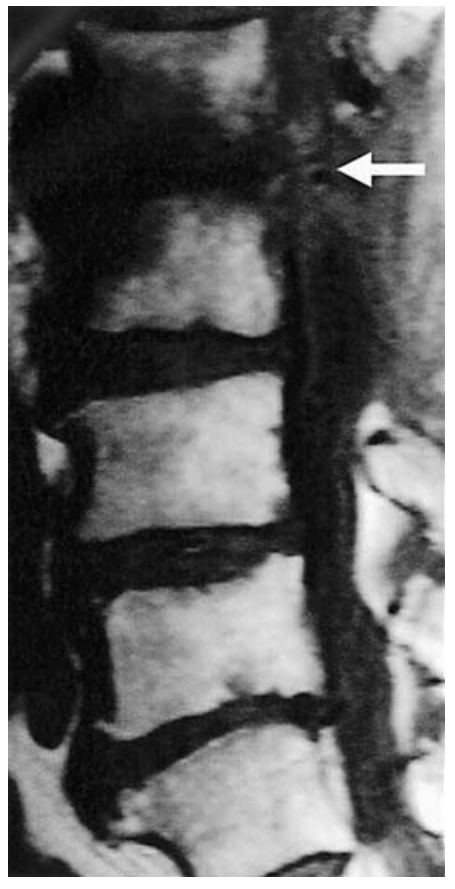

a

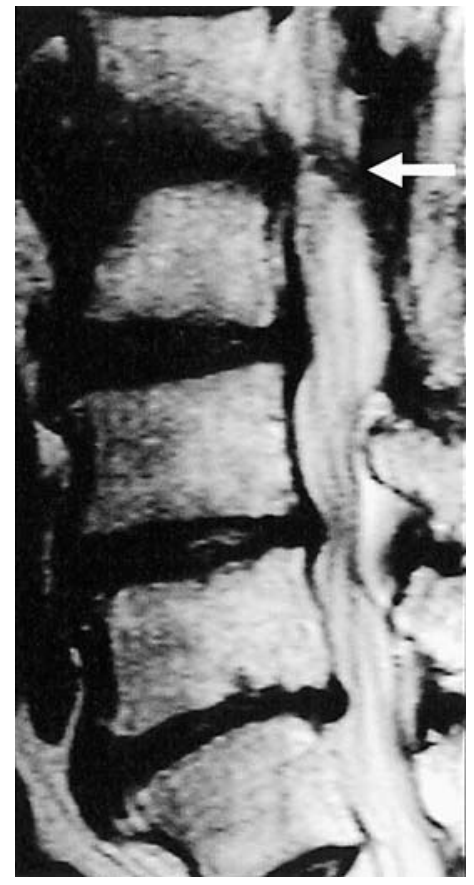

b

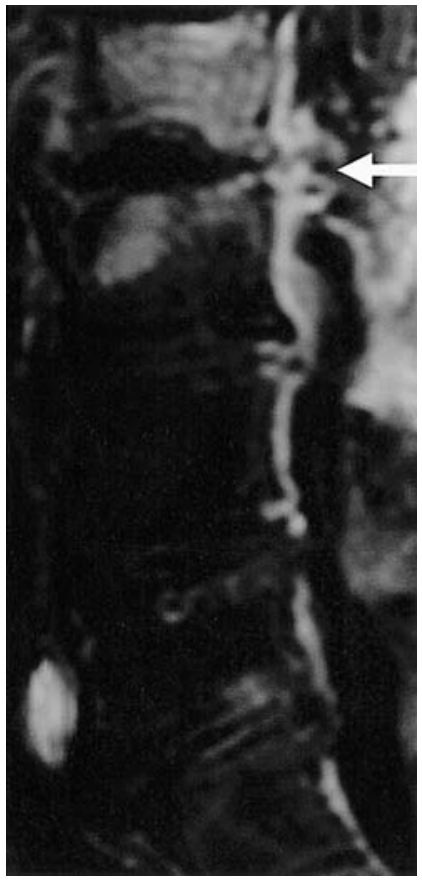

c

図 7 術後 6 力月 MRI

(a) T1 強調画像. L2/3 椎間板および L2, L3 椎体に低信号域を認めた（矢印）.

(b) T2 強調画像. L2/3 椎間板の高信号城は消失していた（矢印）.

(c) Gd 造影画像. L2, 3 椎体後縁の mass も著明に減少していた（矢印）.

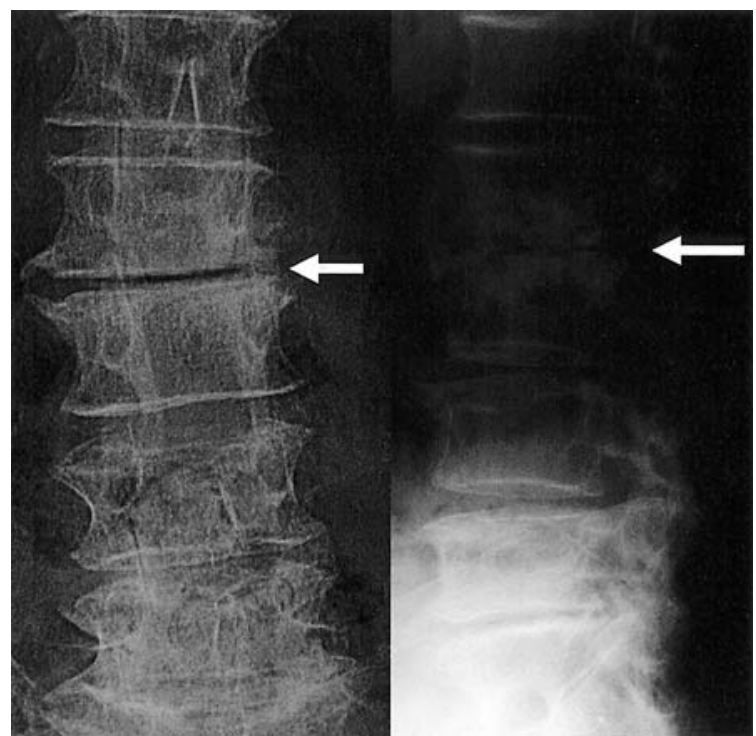

図 8 術後 6 力月単純 X 線. L2 $2 / 3$ 間の狭小化を認め, 終板の骨硬化像を伴っていた（矢 印) 
血液培養でも陰性であった。症状および炎症所見が改 善しないため入院後 3 週で再度 MRI を施行した.

L3/4 間に T2 高信号域を認め Gdにて造影効果を認 めた（図 3). そこで骨シンチを行ったところ L3/4レ ベルに著明な集積像を認めた。責任高位が明らかになつ たので入院後 4 週にL3/4間に経皮的病巣掻爬ドレナー ジを施行した．椎間板からは菌の同定はできなかった. 術後 1 年, 症状および理学的・血液生化学的炎症所見 なく経過良好である。単純 X 線上 L3/4 間の狭小化 を認めた（図 4).

(症例 2)

73 歳女性, 急性型. 白血球 $8040 / \mathrm{mm}^{3}$ であつたが $\mathrm{CRP} 14.0 \mathrm{mg} / \mathrm{dl}$ で内科に入院となり, 抗生剤にて加 療されていた。単純 X 線上骨溶解像は認めなかった (図 5).MRI にて L2/3 椎間に硬膜外膿瘍を伴う炎症 巣を認めた（図 6 ）。入院後 2 週目に意識障害を来た した. 当院神経内科医により脊椎炎から髄膜脳炎を続 発したと診断され，緊急にL2，3 椎弓切除・病巣掻 爬術を行つた。術中に硬膜腹側の非薄化と髄液の漏出 を認め一部ピンホール状穿破を疑つた．後方より椎間 板を摘出したが起炎菌は同定されなかった。術後 IPM $1 \mathrm{~g} /$ 日の静注を行った。3 日目に意識は改善し た. 術後 6 か月, 症状, 理学的. 血液生化学的炎症所 見および MRI 所見ともに改善した（図 7)。単純 X 線上 L $2 / 3$ 間の狭小化, 骨硬化像を認めた（図 8).

\section{考察}

今回の我々の調査結果から化膿性脊椎炎は増加傾向 にあるが，早期から起炎菌の同定なく抗生剂投与がさ れているものが多いため起炎菌の同定が困難となつて いると考えられる。当科での検出率は $56.7 \%$ であり

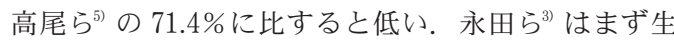
検による早期起炎菌の同定が治療に重要と述べている. 提示した症例 1 では初診時の MRI 施行後に生検を行 うべきであった。また高尾ら ${ }^{5)}$ は化膿性脊椎炎の早期 であればあるほど MRI では捉えられない可能性があ るとして発症後 2 週以内と 4 週後の MRI の検査を推 奨している. 症例 1 では初診時にはっきりした所見は
認められなかつたが発症後 3 週で MRI 上著明な病変 が認められており，初診時 MRI で明らかな所見がな くとも化膿性脊椎炎を疑えば 4 週後に再度 MRI を施 行する必要性が考えられた。化膿性脊椎炎の治療は原 則として保存的治療が行われるが，神経症状を合併し たもの，進行する高度の骨破壊があるもの，保存的治 療に抵抗するものは一般的に手術が行われている。し かし中村ら か) $^{4}$ 易感染性を来たす基礎疾患を有する例 では急性に悪化を来たしやすいので手術による積極的 な治療の必要性を述べている。また川上ら” 膿瘍の存在する例も手術適応と考えている. 今回の研 究結果では合併症, 硬膜外膿瘍の有無は抗生剂の投与 期間には有意な影響を与えていなかつたが，合併症や 硬膜外膿瘍を有する例で疼痛が残存していたり，症例 2 のように髄膜脳炎を併発する例もあったことから早 期の手術的治療の必要性が考えられた。

\section{ま と め}

(1)当科で治療した 39 例の治療経験から化膿性脊椎 炎の診断および治療方針について検討を加えた。

(2)感染高位が認められれば早期に生検を行う必要性 がある。

(3)初診時の MRI で所見を認めなくても化膿性脊椎 炎が疑われれば 4 週後に MRI を再検する必要性があ る.

(4)合併症があり，硬膜外膿瘍を認める例では早期の 手術的治療を検討する必要がある。

\section{参 考 文 献}

1）川上守ら：化膿性脊椎炎の治療成績一とくにその手 術適応と手術時期について, 整形外科, $41: 1492-1498$, 1990

2）国分正一ら：化膿性脊椎炎一診断と治療について一, 臨整外, $13: 307-316,1978$.

3）永田見生ら：化膿性脊椎炎に対する経皮的病巣掻爬ド レナージ，関節外科， $18: 60-64,1999$.

4）中村雅也ら：麻痺を伴った化膿性脊椎炎の治療経験, 整形外科, $43: 647-653,1992$.

5）高尾恒彰ら：化膿性脊椎炎の治療成績の検討，整形外 科と災害外科, $50 ： 1163-1167,2001$. 